Jurnal Sikola: Jurnal Kajian Pendidikan dan Pembelajaran

VOL. 1 NO. 1 SEPTEMBER 2019

http://sikola.ppj.unp.ac.id

Email: sikola@ppj.unp.ac.id

ISSN: 2686-3413 (Print) 2715-1735 (Online)

DOI: https://doi.org/10.24036/sikola.v1i1.3

\title{
Penerapan Model Pembelajaran Think Pair Share untuk Meningkatkan Motivasi Belajar Sosiologi Siswa Kelas XI IPS SMA N 2 Batang Anai
}

\author{
Indah Delviani ${ }^{1}$, Junaidi Junaidi ${ }^{2}$ \\ ${ }^{1,2}$ Universitas Negeri Padang \\ Email: indahdelvianii@gmail.com, junaidiunp@,fis.unp.ac.id
}

\begin{abstract}
Abstrak
Penelitian ini dilatarbelakangi oleh rendahnya motivasi belajar siswa di SMA Negeri 2 Batang Anai khususnya pada kelas XI IPS 2. Berdasarkan hal tersebut upaya yang cocok untuk meningkatkan motivasi belajar siswa dengan adanya rancangan pembelajaran yang tepat, yaitu dengan menggunakan model Think Pair Share. Tujuan penelitian ini adalah mendiskripsikan penerapan model pembelajaran Think Pair Share dalam meningkatkan motivasi belajar kelas XI IPS SMA Negeri 2 Batang Anai. Penelitian ini merupakan penelitian tindakan kelas yang dilaksanakan dengan dua siklus. Siklus pertama dilakukan dua kali pertemuan dan siklus kedua dilakukan dua kali pertemuan. Setiap siklus terdiri dari 4 tahap kegiatan yaitu perencanaan, tindakan, pengamatan dan refleksi. Subjek penelitian adalah siswa kelas XI IPS 2 SMA Negeri 2 Batang Anai yang berjumlah 32 orang. Pada penelitian ini peneliti menetapkan batasan keberhasilan pemahaman kosep siswa pada kategori baik level tengah yaitu $70 \%$. Hasil penelitian menunjukkan bahwa Penerapan Model Pembelajaran Think Pair Share dapat meningkatkan Motivasi Belajar Sosiologi siswa kelas XI IPS 2 SMA Negeri 2 Batang Anai tahun ajaran 2019/2020 yang dibuktikan dengan adanya peningkatan persentase skor Observasi Motivasi Belajar sosiologi dilakukan tindakan pada siklus I skor rata-rata mengalami peningkatan sebesar $12,3 \%$ menjadi $41,98 \%$. Peningkatan juga terjadi pada siklus I ke siklus II yaitu sebesar 34,64 \% menjadi 76,62 \% pada siklus II.
\end{abstract}

Kata Kunci: Think Pair Share, Siswa, dan Motivasi belajar

Abstract

This research is motivated by the low learning motivation of students in SMA Negeri 2 Batang Anai, especially in class XI IPS 2. Based on this, suitable efforts to increase student motivation with the right learning design, using the Think Pair Share model. The purpose of this study is to describe the application of Think Pair Share learning models in increasing motivation to study class XI IPS SMA Negeri 2 Batang Anai. This research is a classroom action research conducted in two cycles. The first cycle was held twice and the second cycle was held twice. Each cycle consists of 4 stages of activity namely planning, action, observation and reflection. The subjects of the study were 32 students of Social Sciences class XI IPS 2 Batang Anai. In this study, researchers set a limit on the success of students' conceptual understanding in the good category of the middle level of 70\%. The results showed that the application of Think Pair Share Learning Model could increase Sociology Learning Motivation of students of class XI IPS 2 of SMA Negeri 2 Batang Anai in the 2019/2020 school year as evidenced by an increase in the percentage of Observation Motivation in sociology Learning taking action in the first cycle, the average score increased by $12.3 \%$ to $41.98 \%$. The increase also occurred in the first cycle to the second cycle which was $34.64 \%$ to $76.62 \%$ in the second cycle.

Keywords: Think Pair Share, Student, and Motivation to learn.

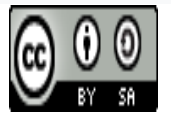

Received: August 5, 2019 Revised: August 8, 2019 Available Online: September 30, 2019

Jurnal Sikola: Jurnal Kajian Pendidikan dan Pembelajaran Vol. 1, No. 1, Th. 2019

ISSN. 2715-1735

Copyright@2019, by Author 


\section{Pendahuluan}

Belajar merupakan proses di mana tingkah laku ditimbulkan atau diubah melalui latihan atau pengalaman (Aunurrahman, 2009). Belajar adalah perubahan tingkah laku yang relatif permanen, perubahan tersebut didapatkan melalui serangkaian latihan dan pengalaman. Adapun aspek-aspek yang berubah yaitu seluruh aspek kepribadian baik berupa perubahan isik maupun perubahan fisikis (Rohim, 2011). Belajar merupakan proses pembangunan pengetahuan dan pemberian makna pada pengalaman belajar, ini bertujuan agar anak dapat membangun pengetahuan sendiri (Pardjono, 2000). Secara umum belajar dapat dipahami sebagai suatu perubahan yang terjadi pada diri seseorang yang berhubungan dengan tingkah laku secara menetap sebagai hasil dari proses pengalaman dan melibatkan proses pengetahuan (Suwardi, 2012). Motivasi merupakan pendorong bagi individu untuk melakukan sesuatu sehingga seseorang dapat menjadi spesialis dalam bidang ilmu pengetahuan (Syardiansah, 2016). Motivasi merupakan faktor penentu keberhasilan belajar jika siswa belajar dengan sungguh-sungguh berarti siswa tersebut memiliki motivasi yang tinggi (Fauziah, Safiah, \& Habibah, 2017). Motivasi dapat menimbulkan tingkat kemauan yang tinggi dalam melaksanakan suatu kegiatan (Suprihatin, 2015). Ada dua jenis motivasi yaitu motivasi intrinsik dan motivasi ekstrinsik, jenis motivasi tersebut sangat diperlukan dalam proses belajar mengajar untuk mendorong siswa agar lebih tekun dan giat belajar (Rahmawati, 2016).

Motivasi sangat berfungsi dalam proses pembelajaran menurut (Hamalik, 2010), fungsi motivasi adalah

1. Berfungsi mendorong timbulnya tingkah laku,

2. Berfungsi sebagai pengarah perbuatan untuk mencapai tujuan yang ingin dicapai,

3. Berfungsi sebagai penggerak tingkah laku seseorang, besar kecilnya motivasi akan menentukan cepat atau lambatnya suatu pekerjaan.

Motivasi berfungsi sebagai mesin, besar kecilnya motivasi yang dimiliki oleh individu menentukan cepat atau lambatnya seseorang tersebut untuk mencapai tujuan (Anggrayni, 2011). Motivasi belajar sangan penting bagi setiap individu. Realita dilapangan yang peneliti temui saat melakukan PLK di SMA Negeri 2 Batang Anai Kabupaten Padang Pariaman adalah banyak siswa yang tidak belajar dengan serius di dalam kelas sehingga tidak mampu memahami dengan baik pelajaran yang disampaikan guru-guru mereka. Sisa sering terlambat masuk kedalam kelas. Kurangnya motivasi belajar siswa dalam pembelajaran sosiologi diebabkan karena tidak tepatnya model pembelajaran yang dipakai guru. Kenyataan motivasi belajar siswa di sekolah ini masih rendah dapat dilihat dari tabel dibawah:

Tabel 1. Data Pendahuluan Motivasi Belajar Siswa kelas X IPS SMA Negeri 2 Batang Anai

\begin{tabular}{llcc}
\hline \multirow{2}{*}{ No } & \multicolumn{2}{c}{ Motivasi belajar siswa } & \multicolumn{2}{c}{$\mathbf{N = 3 0}$} \\
\cline { 3 - 4 } & & Jumlah & $\%$ \\
\hline 1 & Tekun dalam menghadapi tugas & 11 & $36,66 \%$ \\
\hline 2 & Ulet menghadapi kesulitan & 7 & $23,33 \%$ \\
\hline 3 & Menunjukan minat terhadap pembelajaran sosiologi & 11 & $36,66 \%$ \\
\hline 4 & Lebih senang bekerja mandiri & 11 & $36,66 \%$ \\
\hline 5 & Tidak bosan dalam belajar & 8 & $26,66 \%$ \\
\hline 6 & Bisa mempertahankan pendapat & 7 & $23,33 \%$ \\
\hline 7 & $\begin{array}{l}\text { Tidak mudah melepaskan hal-hal yang telah } \\
\text { diyakini }\end{array}$ & 10 & $33,33 \%$ \\
\hline 8 & Senang mencari dan memecahkan masalah soal & 10 & $33,33 \%$ \\
\hline
\end{tabular}

Berdasarkan data pada tabel 1 dapat dilihat bahwa secara umum motivasi belajar siswa masih rendah, karena Cuma berada pada interval 21-40. secara khusus atau setiap indikator motivasi tertinggi berada pada angka $36,66 \%$ yaitu indikator tekun dalam menghadapi tugas dan yang terendah $23,33 \%$ pada indikator ulet menghaapi kesulitan. Untuk pemilihan kelas peneliti 
memilih kelas XI IPS 2. Agar bisa mengatasi masalah tersebut maka penulis menerapkannya model pembelajaran yang cocok yaitu model pembelajan Think Pair Share.

Salah satu cara untuk meningkatkan motivasi belajar adalah penggunaan model pembelajaran Think Pair Share (TPS). model TPS termasuk kedalam tipe pembelajaran kooperati yang dirancang untuk mempengaruhi pola interaksi dan dikembangkan untuk mengoptimalkan hasil belajar siswa (Purwono, 2015). Model pembelajaran Think Pair Share merupakan salah satu model pembelajaran yang memberi kesempatan kepada siswa untuk bekerja mandiri dan bekerja dengan kelompok (Gunawan, 2018). Model pembelajaran Think Pair Share juga merupakan model pembelajaran yang memberikn kesempatan kepada siswa untuk berfikir sendiri, kelompok diskusi dan dilanjutkan berbag kepada teman-teman yang lainnya kegiatan berbagi ini bisa dilakukan didepan kelas (Fauzi, 2018).

\section{Metodologi Penelitian}

Jenis penelitian yang digunakan adalah penelitian tindakan kelas. Menurut Ebbut dalam buku karangan Kunandar mengemukakan bahwa penelitian tindakan kelas adalah kajian sistematik dari upaya perbaikan pelaksanaan pratik pendidikan oleh sekelompok guru dengan melakukan banyak tindakan-tindakan dalam pembelajaran, berdasarkan refleksi mereka mengenai hasil tindakan-tndakan tersebut (Kunandar, 2013). Penelitian tindakan kelas ukan hanya bertujuan untuk meningkatkan hasil belajar, manm juga menngkatkan keahlian guru dan dosen dalam proses pembelajaran, dengan kata kalian PTK tidak hanya mencari penyebab dari pemasalahan tetapi juga memberi pemecahan masalah berupa tindakan untuk mengatasi masalah (Nurlizawati, 2019).

Peningkatan motivasi belajar siswa dapat dilihat dengan melakukan perbandingan antara siklus I dan siklus II. Dalam menentukan persentase skor pada morivasi belajar siswa digunakan rating classes menurut (Arikunto, 2013) dengan rumus $P=\frac{\mathrm{F}}{\mathrm{N}} \times 100 \%$. Pada Motivasi belajar siswa diharapkan mencapai taerget yang telah peneliti tetapkan dan siharapkan mencapai pada kategori baik yaitu dengan interval 61-80.

\section{Hasil dan Pembahasan}

Penelitian ini peneliti lakukan dalam dua siklus, siklus pertama pada penelitian ini terdapat dua kali pertemuan dan begitu juga pada siklus dua, peneliti lakukan dalam dua kali pertemuan penelti melakukan pengamatan dan wawancara.

\section{Siklus Pertama}

Pertemuan pertama siswa masih terlihat kurang memahami pembelajaran dengan menggunakan model pembelajaran yang peneliti gunakan masih baru pertama kali mereka rasakan setelah dijalakan pembelajaran menggunakan model Think Pair Share, model pembelajaran Think Pair Share dapat memberikan peningkatan pada motivasi belajar siswa di kelas XI IPS 2 SMAN 2 atang Ana dari pada model yang biasa digunakan guru di SMA tersebut yaitu dengan menggunakan metode ceramah. Setelah selesai melakkan penelitian pada pertemuan pertama peneliti melanjutkan pada pertemuan kedua, pertemuan ini mengalami peningkatan dibanding pertemuan sebelumnya.

Tabel 2. Peningkatan Motivasi Belajar Sosiologi Siswa Kelas XI IPS 2 pada Tahap Siklus Satu

\begin{tabular}{llccc}
\hline No & \multicolumn{1}{c}{ Indikator } & Pertemuan 1 & Pertemuan 2 & Peningkatan \\
\hline 1 & Tekun dalam menghadapi tugas & $40,62 \%$ & $53,12 \%$ & $12,5 \%$ \\
\hline 2 & Ulet menghadapi kesulitan & $31,25 \%$ & $37,50 \%$ & $6,25 \%$ \\
\hline 3 & Menunjukan minat terhadap & $43,75 \%$ & $50,00 \%$ & $6,25 \%$ \\
\hline
\end{tabular}


Indah Delviani, Junaidi Junaidi Penerapan Model Pembelajaran Think Pair Share untuk Meningkatkan Motivasi Belajar Sosiologi Siswa Kelas XI IPS SMA N 2 Batang Anai Kabupaten Padang Pariaman

\begin{tabular}{lllll}
\hline & pembelajaran sosiologi & & & \\
\hline 4 & Lebih senang bekerja mandiri & $40,62 \%$ & $46,88 \%$ & $6,26 \%$ \\
\hline 5 & Tidak bosan dalam belajar & $34,37 \%$ & $43,75 \%$ & $9,38 \%$ \\
\hline 6 & Dapat mempertahankan pendapat & $34,37 \%$ & $40,62 \%$ & $6,25 \%$ \\
\hline 7 & $\begin{array}{l}\text { Tidak mudah melepaskan hal-hal } \\
\text { yang diyakini }\end{array}$ & $37,50 \%$ & $46,88 \%$ & $9,38 \%$ \\
\hline 8 & $\begin{array}{l}\text { Senang mencari dan memecahkan } \\
\text { masalah soal }\end{array}$ & $40,62 \%$ & $50,00 \%$ & $9,38 \%$ \\
\hline
\end{tabular}

Sumber: Diolah dari Data Observasi Siklus I

Siklus satu pertemuan pertama terdapat peningkatan pada setiap indikator motivasi belajar dan rata-rata peningkatan pada pra tindakan dan pertemuan pertama adalah $8,20 \%$. Peningkatan yang paling tinggi ada pada indikator senang mencari dan memecahkan masalah yaitu $12,5 \%$. Sedangkan yang terendah yaitu tekun dalam menghadapi tugas $6,25 \%$, menunjukan minat terhadap pembelajaran sosiologi $6,25 \%$, lebih senang bekerja mandiri $6,25 \%$, dan tidak mudah bosan dalam blajar $6,25 \%$. Pada pertemuan dua juga jadi peningkatan pada motivasi belajar siswa yaitu sebanyak $8,20 \%$, jika disimpulkan menurut Arikunto motivasi belajar siswa kelas XI IPS 2 masih kurang yaitu masih pada interval 41-60 belum mencapai standar minimal yang penulis tetapkan yaitu 70. Agar terdapat peningkatan Motivasi belajar pada siswa kelas peneliti melakukan konsultasi bagaimana cara meningkatkan motivasi belajar siswa. dan melakukan wawancara dengan siswa bagaimana cara yang tepat untuk meningkatkan motivasi belajar hingga semua indikator motivasi dapat tergolong baik. Peneliti meneruskan pada siklus dua dengan cara melakukan perubahan agar dapat memperbaiki kekurangan pada siklus satu.

\section{Siklus Dua}

Siklus dua ini terjadi peningkatan indikator motivasi belaja secara keseluruhan dari pada tahap siklus satu, peningkatan motivasi belajar dapat dilihat dibawah ini.

\section{Tabel 3. Hasil Tingkatan Motivasi Belajar Sosiologi Siswa Kelas XI IPS 2 pada Siklus II}

\begin{tabular}{llccc}
\hline No & \multicolumn{1}{c}{ Indikator } & $\begin{array}{c}\text { Persentase } \\
\text { Pertemuan 3 }\end{array}$ & $\begin{array}{c}\text { Persentase } \\
\text { Pertemuan 4 }\end{array}$ & Peningkatan \\
\hline 1 & Tekun dalam menghadapi tugas & $66,66 \%$ & $86,66 \%$ & $20,00 \%$ \\
\hline 2 & Ulet menghadapi kesulitan & $73,33 \%$ & $80,00 \%$ & $6,33 \%$ \\
\hline 3 & $\begin{array}{l}\text { Menunjukan minat terhadap } \\
\text { pembelajaran sosiologi }\end{array}$ & $70,00 \%$ & $83,00 \%$ & $13,00 \%$ \\
\hline 4 & Lebih senang bekerja mandiri & $80,00 \%$ & $86,66 \%$ & $6,66 \%$ \\
\hline 5 & Tidak bosan dalam belajar & $73,33 \%$ & $80,00 \%$ & $6,33 \%$ \\
\hline 6 & Dapat mempertahankan pendapat & $76,66 \%$ & $76,66 \%$ & $0 \%$ \\
\hline 7 & $\begin{array}{l}\text { Tidak mudah melepaskan hal-hal } \\
\text { yang diyakini }\end{array}$ & $73,33 \%$ & $76,66 \%$ & $3,33 \%$ \\
\hline 8 & $\begin{array}{l}\text { Senang mencari dan memecahkan } \\
\text { masalah soal }\end{array}$ & $60,00 \%$ & $83,00 \%$ & $23,00 \%$ \\
\hline & & & $9,83 \%$ \\
\hline
\end{tabular}

Sumber: Diolah dari data observasi siklus dua

Siklus II pertemuan ketiga dan pertemuan keempat motivasi belajar siswa mengalami peningkatan dan mencapai nilai minimal yang ditentukan yaitu sebanyak 70 , pada pertemuan ke 3 ada dua indikator yang belum mencapi nilai minimal yang ditentukan yaitu tekun dalam menghadapi tugas $66,66 \%$ dan senang mencari dan memecahkan masalah soal $60,00 \%$. Sedangkan pada pertemuan keempat semua indikator telah lebih dari 70 dengan nilai tertinggi 
tekun menghadapi tugas dan lebih senang bekerja mandiri $86,66 \%$, yang terendah dapat mempertahankan pendapat dan tidak mudah melepaskan hal yang diyakini 76,66\%. Pada siklus dua ini motivasi belajar mengalami peningkatan sebanyak 9,83\%. Oleh karena itu peneliti menghentikan penelitian hingga siklus dua. Karena berdasarkan data yang peneliti dapat dari siklus kedua motivasi belajar siswa sudah baik sehingga siklus berikutnya tidak diperlukan lagi.

Observasi yang peneliti lakukan di kelas XI IPS 2 SMA Negeri 2 Batang Anai pada umumnya seiap pertemuan mengalami pningkatan disetiap siklusnya dengan menggunakan model Think Pair Share. Pada awal pertemuan yaitu siklus I masih ada beberapa siswa yang tidak antusias dalam mengikuti proses pembelajaran dan masih ada siswa yang bingung dalam proses pembelajaran. Siklus satu pertemun duaa siswa mulai antusias dengan pembelajaran menggunakan model Think Pair Share dalam prses pembelajaran berlangsung masih ada siswa yang sedikt ribut saat berdikusi dan pada siklus kedua pertemuan tiga siswa sudah mulai bisa memahami materi dan mulai terbiasa dengan model Think Pair Share Pada siklus II pertemuan keempat siswa sudah mulai memperlihatkan ketertarikannya pada pelajaran sosiologi.

Tabel 5. Hasil Siklus Dua

\begin{tabular}{|c|c|c|c|c|c|c|c|c|}
\hline \multirow[t]{2}{*}{ No. } & \multirow[t]{2}{*}{ Indikator } & \multirow[t]{2}{*}{ Deskriptor } & \multicolumn{2}{|c|}{ Pertemuan 3} & \multicolumn{2}{|c|}{ Pertemuan 4} & \multirow{2}{*}{$\begin{array}{c}\begin{array}{c}\text { Pening } \\
\text { katan }\end{array} \\
\%\end{array}$} & \multirow{2}{*}{$\begin{array}{c}\text { Rata- } \\
\text { rata }\end{array}$} \\
\hline & & & Jlh & $\%$ & $\mathrm{Jlh}$ & $\%$ & & \\
\hline 1 & $\begin{array}{l}\text { Tekun dalam } \\
\text { menghadapi } \\
\text { tugas }\end{array}$ & $\begin{array}{l}\text { Mengerjakan soal-soal } \\
\text { yang diberikan oleh } \\
\text { guru dengan sungguh- } \\
\text { sungguh }\end{array}$ & 20 & 66,66 & 26 & 86,66 & 20 & 76,66 \\
\hline 2 & $\begin{array}{l}\text { Ulet } \\
\text { menghadapi } \\
\text { kesulitan }\end{array}$ & $\begin{array}{l}\text { Berusaha mengerjakan } \\
\text { soal sulit dengan } \\
\text { bekerjasama dengan } \\
\text { pasangan. }\end{array}$ & 22 & 73,33 & 24 & 80,00 & 6,67 & 76,66 \\
\hline 3 & $\begin{array}{l}\text { Menunjukan } \\
\text { minat terhadap } \\
\text { pelajaran } \\
\text { sosiologi }\end{array}$ & $\begin{array}{l}\text { Tertarik dengan } \\
\text { berbagai permasalahan } \\
\text { yang berkembang } \\
\text { dalam diskusi. }\end{array}$ & 21 & 70,00 & 25 & 83,00 & 13 & 76,5 \\
\hline 4 & $\begin{array}{l}\text { Lebih senang } \\
\text { bekerja mandiri }\end{array}$ & $\begin{array}{l}\text { Tidak mencontek } \\
\text { ketika mengerjakan } \\
\text { soal soal mandiri yang } \\
\text { diberikan guru. }\end{array}$ & 24 & 80,00 & 26 & 86,66 & 6,66 & 83,33 \\
\hline 5 & $\begin{array}{l}\text { Tidak bosan } \\
\text { dalam belajar }\end{array}$ & $\begin{array}{l}\text { Tidak bosan dengan } \\
\text { pelajaran yang } \\
\text { diberikan guru. }\end{array}$ & 22 & 73,33 & 24 & 80,00 & 6,67 & 76,66 \\
\hline 6 & $\begin{array}{l}\text { Dapat } \\
\text { mempertahank } \\
\text { an pendapat }\end{array}$ & $\begin{array}{l}\text { Aktif dalam } \\
\text { menyatakan pendapat } \\
\text { dikelas. }\end{array}$ & 23 & 76,66 & 23 & 76,66 & 0 & 76,66 \\
\hline 7 & $\begin{array}{l}\text { Tidak mudah } \\
\text { melepaskan } \\
\text { hal-hal yang } \\
\text { diyakini }\end{array}$ & $\begin{array}{l}\text { Teguh dengan } \\
\text { pendapat sendiri. }\end{array}$ & 22 & 73,33 & 23 & 76,66 & 3,33 & 74,99 \\
\hline
\end{tabular}


Indah Delviani, Junaidi Junaidi

Penerapan Model Pembelajaran Think Pair Share untuk Meningkatkan Motivasi Belajar Sosiologi Siswa Kelas XI IPS SMA N 2 Batang Anai Kabupaten Padang Pariaman

\begin{tabular}{|c|c|c|c|c|c|c|c|c|}
\hline 8 & $\begin{array}{l}\text { Senang } \\
\text { mencari dan } \\
\text { memecahkan } \\
\text { masalah- } \\
\text { masalah soal }\end{array}$ & $\begin{array}{l}\text { Semangat dalam } \\
\text { pembelajaran sosiologi. }\end{array}$ & 18 & 60,00 & 25 & 83,00 & 23 & 71,5 \\
\hline & Rata-rata & & & 71,66 & & 81,58 & & 76,62 \\
\hline
\end{tabular}

\section{Sumber: Data observasi}

Dari data di atas dilihat bagaimana perbandingan pada siklus dua pertemuan tiga dan pertemuan empat peningkatan yang terjadi cukup signifikan. Pada indikator tekun dalam menghadapi tugas 7,20\%, ulet menghadapi kesulitan 6,67\%, menunjukan minat terhadap peajaran sosiologi $13 \%$, lebih senang bekerja mandiri 6,66, tidak bosan dalam belajar 6,67, dapat mempertahankan pendapat 6,66 , tidak mudah melepaskan hal yang diyakini 3,33\% dan senang mencari dan memecahkan masalah soal $23 \%$. Peningkatan pada pertemuan empat terdapat sudah terpenuhinya semua inikator, yaitu dengan interval 61-80 dengan kategori baik. Agar bisa melihat peningkatan motivasi elajar siswa dari siklus satu dan siklus dua dapat dilihat seagai beribut.

\section{Tabel 6. Data Hasil Perbandingan Dua Siklus}

\begin{tabular}{|c|c|c|c|c|c|c|c|}
\hline No & Indikator & Deskriptor & $\begin{array}{c}\text { Pra } \\
\text { tinda } \\
\text { kan }\end{array}$ & $\begin{array}{l}\text { Siklus } \\
\text { I }\end{array}$ & $\begin{array}{l}\text { Pening } \\
\text { katan }\end{array}$ & $\begin{array}{l}\text { Siklus } \\
\text { II }\end{array}$ & $\begin{array}{l}\text { Pening } \\
\text { katan }\end{array}$ \\
\hline 1 & $\begin{array}{l}\text { Tekun dalam } \\
\text { menghadapi } \\
\text { tugas }\end{array}$ & $\begin{array}{l}\text { Mengerjakan soal-soal } \\
\text { yang diberikan oleh guru } \\
\text { dengan sungguh-sungguh }\end{array}$ & 34,37 & 46,87 & 12,5 & 76,66 & 29,79 \\
\hline 2 & $\begin{array}{l}\text { Ulet menghadapi } \\
\text { kesulitan }\end{array}$ & $\begin{array}{l}\text { Berusaha mengerjakan } \\
\text { soal sulit dengan } \\
\text { bekerjasama dengan } \\
\text { pasangan. }\end{array}$ & 21,88 & 34,37 & 12,49 & 76,66 & 42,29 \\
\hline 3 & $\begin{array}{l}\text { Menunjukan } \\
\text { minat terhadap } \\
\text { pelajaran } \\
\text { sosiologi }\end{array}$ & $\begin{array}{l}\text { Tertarik dengan berbagai } \\
\text { permasalahan yang } \\
\text { berkembang dalam } \\
\text { diskusi. }\end{array}$ & 37,50 & 46,87 & 9,37 & 76,5 & 29,63 \\
\hline 4 & $\begin{array}{l}\text { Lebih senang } \\
\text { bekerja mandiri }\end{array}$ & $\begin{array}{l}\text { Tidak mencontek ketika } \\
\text { mengerjakan soal soal } \\
\text { mandiri yang diberikan } \\
\text { guru. }\end{array}$ & 34,37 & 43,75 & 9,38 & 83,33 & 39,58 \\
\hline 5 & $\begin{array}{l}\text { Tidak bosan } \\
\text { dalam belajar }\end{array}$ & $\begin{array}{l}\text { Tidak bosan dengan } \\
\text { pelajaran yang diberikan } \\
\text { guru. }\end{array}$ & 28,12 & 39,06 & 10,94 & 76,66 & 37,6 \\
\hline 6 & $\begin{array}{l}\text { Dapat } \\
\text { mempertahankan } \\
\text { pendapat }\end{array}$ & $\begin{array}{l}\text { Aktif dalam menyatakan } \\
\text { pendapat dikelas. }\end{array}$ & 25,00 & 37,49 & 12,49 & 76,66 & 39,17 \\
\hline
\end{tabular}


Indah Delviani, Junaidi Junaidi Penerapan Model Pembelajaran Think Pair Share untuk Meningkatkan Motivasi Belajar Sosiologi Siswa Kelas XI IPS SMA N 2 Batang Anai Kabupaten Padang Pariaman

\begin{tabular}{|c|c|c|c|c|c|c|c|}
\hline 7 & $\begin{array}{l}\text { Tidak mudah } \\
\text { melepaskan hal- } \\
\text { hal yang diyakini }\end{array}$ & $\begin{array}{l}\text { Teguh dengan pendapat } \\
\text { sendiri. }\end{array}$ & 28,12 & 42,19 & 13,98 & 71,5 & 29,31 \\
\hline \multirow[t]{2}{*}{8} & $\begin{array}{l}\text { Senang mencari } \\
\text { dan memecahkan } \\
\text { masalah-masalah } \\
\text { soal }\end{array}$ & $\begin{array}{l}\text { Semangat dalam } \\
\text { pembelajaran sosiologi. }\end{array}$ & 28,12 & 45,31 & 17,19 & 76,62 & 31,31 \\
\hline & Rata-rata & & 29,68 & 41,98 & 12,29 & 76,82 & 34,84 \\
\hline
\end{tabular}

Dari data di atas ada peningkatan motivasi belajar siswa dari siklus I 46,87\% dan meningkat lagi pada siklus II menjadi 76,66\%. Pada indikator ulet menghadapi tugas siklus I $34,37 \%$ dan meningkat lagi pada siklus II menjadi $76,66 \%$. Indikator menunjukan minat terhadap mata pelajaran sosologi siklus I menjadi $46,87 \%$ dan meningkat lagi pada siklus II menjadi 76,5\%. Indikator lebih senang bekerja mandiri siklus I menjadi $43,75 \%$ dan meningkat lagi pada siklus II menjadi $83,33 \%$. Indikator tidak bosan dalam belajar siklus I menjadi 39,06\% dan meningkat lagi pada menjadi $76,66 \%$ indikator dapat mempetahankan masalah siklus I menjadi $37,49 \%$ dan meningkat lagi pada siklus II menjadi 76,66\%. Indikator tidak mudah melepaskan hal-hal yang yakini pada siklus I menjadi 37,49\% kemudian meningkat lagi pada siklus II menjadi $76,66 \%$. Senang mencari dan memecahkan masalah-masalah soal $28,12 \%$, meningkat pada siklus I 42,19\%, kemudian meningkat lagi pada siklus II 71,5\%. Salah satu upaya yang daapt dilakukan untuk meningkatkan motivasi siswa denganmemberitahu $\mathrm{h}$ asil kemampuan siswa agar menumbuhkan kompetisi antar kelompok dan antar sesama siswa. (Sylvia, 2012)

\section{Penutup}

Dari hasil peneltian tindakan kelas yang telah dilakukan di kelas XI IPS 2 SMA Negeri 2 Batang Anai sebagai berikut:

1. Penggunakan model Think Pair Share bisa meningkatkan motivasi belajar siswa. Hal ini dapat dibuktikan dari peningkatan hasil observasi sklus pertama dan siklus kedua.

2. Secara keselurahan motivasi belajar siswa mengalami peningkatan. Pada tahap pertemuan pertama motivasi belajar siswa masih sangat rendah dikarenakan tidak ada satupun siswa yang mencapai target keberhasilan yang telah ditentukan, pertemuan pertama terdapat $37,88 \%$ menngkat pada pertemuan kedua $46,09 \%$ siswa lalu meningk lagit pada pertemuan ketiga pada ketegori baik $71,66 \%$ siswa dan mengalami peningkatan pada pertemuan empat $81,58 \%$ siswa.

3. Pembelajaran sosiologi dengan menggunakan model Think Pair Share dapat meningkatkan motivasi belajar siswa.

\section{Daftar Pustaka}

Anggrayni, Y. (2011). Faktor-Faktor Yang Mempengaruhi Motivasi Belajar Siswa dalam Mengikuti Pelajaran Pengawetan Di SMK Negeri 1 Pandak, Bantul, D.I. Yogyakarta (Studi Kasus SMK Negeri 1 Pandak Kelas X Teknologi Hasil Pertanian 1).

Arikunto. (2013). Prosedur Penelitian: Suatu Pendekatan Praktik. Jakarta: Rineka Cipta.

Aunurrahman. (2009). Belajar dan Pembelajaran. Bandung: Alfabeta.

Fauzi, ahsan. (2018). Implementasi Model Pembelajaran Kooperatif Tipe Think Pair Share (TPS) dan

Talking Stick Untuk Meningkatkan Keaktifan Belajar Pada Kompetensi Dasar Memproses Buku 
Besar Siswa Kelas X Akuntansi 1 SMK 17 Magelang Tahun Ajaran 2017/2018. (1), 430-439.

Fauziah, Safiah, I., \& Habibah, S. (2017). Upaya Meningkatkan Motivasi Belajar Siswa Melalui

Lesson Study di Kelas V SD Impres 59 kabupaten sorong. Jurnal Ilmiah Pendidikan Guru Sekolah Dasar, 2(motivasi belajar siswa), 30-38.

Gunawan, A. (2018). Pembelajaran Think Pair Share Untuk Meningkatkan Social Skill Siswa Mata Pelajaran Kewirausahaan.

Hamalik, O. (2010). Proses Belajar Mengajar. Jakarta: PT. Bumi Aksara.

Kunandar. (2013). Langkah Mudah Penelitian Tindakan Kelas Sebagai Pengembangan Profesi Guru. Jakarta: Rajawali Pers.

Nurlizawati. (2019). Penerapan Model Pembelajaran Tutor Teman Sebaya Di SMAN 1 Pasaman. Universitas Negeri Padang, 6(1), 33-41.

Pardjono. (2000). Konsepsi Guru Tentang Belajar Dan Mengajar Dalam Perspektif Belajar Aktif. Jurnal Psikologi (Yogyakarta), 27(2), 73-83. https://doi.org/10.22146/jpsi.7000

Purwono, A. (2015). Penerapan Model Pembelajaran Kooperatif Tipe Think Pair Share (Tps ) Pada Materi Dasar Elektronika Di Kelas Ix Smp Negeri 6 Petarukan.

Rahmawati, R. (2016). Faktor-Faktor Yang Mempengaruhi Motivasi Belajar Siswa Kelas X Sma N 1 Piyungan Pada Mata Pelajaran Ekonomi Tahun Ajaran 2015/2016. Jurnal Pendidikan Dan Ekonomi, 5(4), 326-336.

Rohim, A. (2011). Pengaruh Minat Belajar Terhadap Prestasi Belajar Siswa Pada Bidang Studi PAI. 195.

Suprihatin, S. (2015). Upaya Guru Dalam Meningkatkan Motivasi Belajar Siswa. 3(1), 73-82.

Suwardi. (2012). Pengaruh Minat Belajar Terhadap Prestasi Belajar Siswa Pada Mata Pelajaran Pendidikan Agama Islam di SMK NEGERI 1 Sengkang Kabupaten Wajo. 10(9), 32.

Syardiansah. (2016). Hubungan Motivasi Belajar dan Minat Belajar terhadap Prestasi Belajar Mahasiswa Mata Kuliah Pengantar Manajemen ( Studi kasus Mahasiswa Tingkat I EKM A Semester II ). Jurnal Manajemen Dan Keuangan, 5(1), 443.

Sylvia, I. (2012). Upaya Meningkatkan Kemampuan Berpikir Kritis Siswa dalam Mata Pelajaran Sejarah dengan Pembelajaran Snowball Trhowing. Diakronika, XII(02), 163-182. https://doi.org/10.31227/osf.io/76cym 